\title{
Phytochemical Analysis, Multi-Element Composition and Biological Activities of Extracts and Lupenone from Albizia inundata (Mart.) Barneby \& J.W.Grimes
}

\author{
Eberson M. J. Andrade, ${ }^{a}$ Jéssica S. Teixeira, ${ }^{b, c}$ Dahara K. C. Silva, ${ }^{b, c}$ Tatiana B. dos Santos, ${ }^{b, c}$ \\ Maria G. A. Korn, ${ }^{d}$ Hugo N. Brandão, ${ }^{e}$ Caline G. Ferraz, ${ }^{f}$ Cássio S. Meira, ${ }^{c}$ Milena B. P. Soares, ${ }^{c}$ \\ Elisava T. Guimarães, ${ }^{b, c}$ Lourdes C. S. Neta ${ }^{a}$ and Aníbal F. S. Júnior ${ }^{\circledR *, a, b}$ \\ ${ }^{a}$ Departamento de Ciências Exatas e da Terra, Universidade do Estado da Bahia, \\ 41195-000 Salvador-BA, Brazil \\ ${ }^{b}$ Departamento de Ciências da Vida, Universidade do Estado da Bahia, 41195-000 Salvador-BA, \\ Brazil \\ 'Instituto Gonçalo Moniz, Fundação Oswaldo Cruz, 40296-710 Salvador-BA, Brazil \\ ${ }^{d}$ Instituto de Química, Universidade Federal da Bahia, 40170-115 Salvador-BA, Brazil \\ ${ }^{e}$ Departamento de Saúde, Universidade Estadual de Feira de Santana, \\ 44036-900 Feira de Santana-BA, Brazil \\ ${ }^{f}$ Centro de Ciências Exatas e Tecnológicas, Universidade Federal do Recôncavo da Bahia, \\ 41195-001 Cruz das Almas-BA, Brazil
}

\begin{abstract}
In this study, antimicrobial activity of extracts and lupenone from A. inundata (Fabaceae, Mimosoideae), were tested. In addition, the multi-element composition of the leaves, bark and stems (heartwood) of A. inundata was evaluated using inductively coupled plasma optical emission spectrometry (ICP OES). Lupenone was isolated in the petroleum ether extract of leaves, for the first time. Biological assays were conducted to evaluate the antimicrobial (antibacterial, antifungal and antiparasitic) of extracts, their fractions and lupenone. The results showed antimicrobial and antileishmanial activity of these compounds, which may be useful for obtaining a chemical composition and biological activity database on Albizia species. For multi-element composition, we found the mean concentrations (minimum-maximum) of $\mathrm{Al}, \mathrm{Ca}, \mathrm{Cr}, \mathrm{Cu}, \mathrm{Fe}, \mathrm{K}, \mathrm{Mg}, \mathrm{Mn}, \mathrm{Ni}, \mathrm{P}$, $\mathrm{V}$ and $\mathrm{Zn}$ in the samples ranged between 0.06 and $265.41 \mu \mathrm{g} \mathrm{g}^{-1}$. Concentration ranges of $\mathrm{Cu}, \mathrm{Fe}$, $\mathrm{Mn}$ and $\mathrm{Zn}$ are large, which makes these samples as additional sources of these macronutrients.
\end{abstract}

Keywords: Albizia inundata, lupenone, biological activity, multi-element composition

\section{Introduction}

The genus Albizia belongs to the Fabaceae family, subfamily Mimosoideae, includes about 140 species, mainly woody trees and shrubs native to tropical Asia, also found in South Africa and South America. ${ }^{1-4}$ The genus Albizia includes several species including the native congeners A. hassleri, A. niopoides, A. inundata, A. pedicellaris, A. polycephala and A. polyphylla, distributed throughout Brazil, recommended for the reforestation of areas degraded by have characteristics of rapid botanical growth. Some species of this genus have been reported to produce a wide

*e-mail: afjunior@uneb.br range of secondary metabolites, as triterpenoid saponins, flavonoids, alkaloids, among others. ${ }^{5}$ Some studies about genus Albizia revealed potential cytotoxic activity in vitro against tumor cell lines. ${ }^{6-11}$

Albizia inundata (Mart.) Barneby \& J.W.Grimes, known by the popular names of "timbó-branco," "muscovado," "biguazeiro," “canafístula" and "muquém," presents a wide geographic distribution in South America, occurring naturally in Argentina, Bolivia, Brazil, Paraguay and Uruguay. ${ }^{12}$ In Brazil, the species are native to the Amazon Region, São Francisco Valley and Pantanal Matogrossense, in riparian forests and floodplain. ${ }^{13}$ Previous phytochemical studies reported the isolation of oleanane triterpenoid saponins from an extract of the 
aerial parts of Albizia inundata, and their bioactivity against human colon cells (HCT116) and melanoma cells (B16F10 and SKMEL28). ${ }^{14,15}$ In literature, there are no reports of antibacterial, antifungal, antitrypanocidal and antileishmanial activities for $A$. inundata.

Chemical aspects and biological activity of $A$. inundata have been poorly explored, despite the potential of this plant as a source of bioactive compounds. In vitro cellular cytotoxicity assays have as main parameter to provide information on the safety of the various drugs or compounds, being the first step to evaluate the biocompatibility of any substance for the biomedical use. ${ }^{16}$

Determination of inorganic components in medicinal plants is of great interest because chemical elements can be catalysts of biochemical reactions in plants and to influence in their therapeutic action on the human health. ${ }^{17,18}$ Most multi-element analysis, in biological samples, require pretreatment of the samples prior to quantification by analytical techniques, such as, inductively coupled plasma optical emission spectrometry (ICP OES); inductively coupled plasma mass spectrometry (ICP-MS); atomic absorption spectrometry with graphite furnace (GF AAS), flame (FAAS) and hydride generation (HG AAS). ${ }^{19-23}$ ICP OES is a sensitive multi-element technique, used in the analysis of biological samples due to its advantages, which consists of the quantification of elements through the emission of electromagnetic radiation, generated from the excitation of their atoms or ions. ${ }^{24}$ In the literature, there are no reports of macro and micronutrient evaluation in species of the genus Albizia, which may contribute to the knowledge of their inorganic constituents.

In this study, lupenone was isolated in the petroleum ether extract of leaves from Albizia inundata (Mart.) Barneby \& J.W.Grimes, for the first time, by chromatographic techniques and identified by one-dimensional nuclear magnetic resonance $\left({ }^{1} \mathrm{H}\right.$ and ${ }^{13} \mathrm{C}$ NMR). For evaluation of antimicrobial activities (antibacterial, antifungal and antiparasitic) of extracts and lupenone from A. inundata, biological assays and ultrastructural analysis were conducted. In addition, ICP OES was used for multi-element analysis in aerial parts of A. inundata. This work is relevant to expand the studies about chemical and biological potential of this species and to evaluate the multi-element composition of the leaves, bark and stems (heartwood) of A. inundata.

\section{Experimental}

Plant materials and preparation of plant extracts

The aerial parts of Albizia inundata (Mart.) Barneby \& J.W.Grimes were collected near the Bahia State
University, Juazeiro, Bahia, $368 \mathrm{~m}$ above sea level, with geolocation: S 9²5'13.2”; W 40²9'10.1” (-9.420346, -40.486145), on 19 February 2016, during the period of plant harvesting. The plant material was identified and specimen voucher No. 61231 was deposited at the Herbarium Radambrasil GRN/Ba, Salvador, Bahia, Brazil. The activity of access to the genetic heritage was registered (Registration No. A624ED2) in the National General Heritage Management and Associated Traditional Knowledge Management System (SisGen), in Brazil.

Dried aerial parts, leaves $(574.80 \mathrm{~g})$; stems (405.28 g) and stem bark (1004.70 g) of A. inundata were ground and cut (stem/core) into small pieces, with a knife mill (Marconi-MA680; Macro Vertical Rotor Mill with fixed and mobile knives, Piracicaba, Brazil) and subjected to the successive extraction by the maceration process with petroleum ether, hexane and methanol (Vetec and Synth, analytical grade, São Paulo, Brazil), with three successive exchanges for each solvent, every $72 \mathrm{~h}$. After, the solvents were removed using a rotary evaporator under reduced pressure $\left(\mathrm{IKA}^{\circledR} \mathrm{RV} 10\right.$ digital, IKA $®$ HB 10 Basic, Rio de Janeiro, Brazil), at a temperature of $30-55^{\circ} \mathrm{C}$, to obtain the respective crude methanolic extracts: leaves (EML), stem bark (SMSB), stem (SEM), and petroleum ether of the leaves (EPEL), with 12.0, 3.30, 2.09 and 3.14\% yield, respectively.

\section{General experimental procedures}

Initially, the extracts were subjected to silica gel 60 chromatography (70-230 mesh, Merck and Vetec, São Paulo, Brazil) and comparative thin layer chromatography (TLC) techniques using aluminum chromate plates coated with silica gel, $0.20 \mathrm{~mm}$, with fluorescent indicator UV254/365 (Macherey-Nagel ${ }^{\circledR}$; Merck, São Paulo, Brazil), as well as preparative thin layer chromatography (CCDP) on glass plates of size $20 \times 20 \mathrm{~cm}$, prepared with silica gel 60 (PF254-366, Merck, São Paulo, Brazil). All the chemical reagents used were purchased from Merck (Darmstadt, Germany) and Sigma Chemical Co. (St. Louis, MO, USA) and were of analytical grade. The water was purified using the Milli-Q purification system from Millipore (Bedford, MA, USA).

The petroleum ether extract from the leaves (initial mass $18.03 \mathrm{~g}$ ) of A. inundata was selected for continuation of the fractionation studies. The NMR spectra were obtained in Agilent DD2 (Santa Clara, CA, USA) spectrometers operating at $500 \mathrm{MHz}\left({ }^{1} \mathrm{H}\right)$ and, 75 and $125 \mathrm{MHz}\left({ }^{13} \mathrm{C}\right)$. The samples were solubilized in deuterated chloroform $\left(\mathrm{CDCl}_{3}\right)$, having the internal reference standard $(\delta=0 \mathrm{ppm})$, tetramethylsilane (TMS) for ${ }^{1} \mathrm{H}$ NMR and $\mathrm{CDCl}_{3}$ for ${ }^{13} \mathrm{C}$ 
NMR. Chemical shifts were expressed in ppm values $(\delta)$ given in relation to TMS. The coupling constants $(J)$ were measured in hertz $(\mathrm{Hz})$.

\section{Lupenone isolation}

EPEL from A. inundata (18.34 g) was fractionated on a silica gel chromatographic column (CC) and eluted with solvent mixture with gradual increase of polarity (petroleum ether/ethyl acetate (9:1); petroleum ether/ethyl acetate (8:2), petroleum ether/ethyl acetate (7:3); ethyl acetate (100\%); methanol (100\%)) resulting in 10 fractions (EPEL1-10). The fraction EPEL3 $(1.779 \mathrm{~g}$ ) was subjected to the silica gel CC, eluted with polarity gradient (petroleum ether $(100 \%)$, petroleum ether/dichloromethane (9:1); dichloromethane (100\%), dichloromethane/ ethyl acetate (7:3), ethyl acetate (100\%), ethyl acetate/methanol (1:1); methanol (100\%)), resulting in 195 fractions, after monitoring by TLC. The subfractions: EPEL3.24 (42.7 mg), EPEL3.28 (58.3 mg) and EPEL3.29 (34.5 mg) were subjected to preparative TLC eluted with (hexane/chloroform/ethyl acetate (10: 0.5:0.4); hexane/dichloromethane/ethyl acetate (11:0.5:0.5) (2x)) and (hexane/chloroform/ethyl acetate (11: 0.5: 0.4) (3x)), respectively. The subfractions obtained F3.24.4 (5.2 mg), F3.28.3 (3.9 mg) and F3.29.3 (2.0 mg) resulted in lupenone.

\section{Test microorganisms}

Bacteria and fungi were obtained from André Tosello Tropical Research and Technology Foundation (Campinas, Brazil) and were as follows: Gram-positive bacteria (Bacillus subtilis ATCC 6633, Micrococcus luteus ATCC 10240 and Staphylococcus aureus ATCC 6538); Gram-negative bacteria (Escherichia coli ATCC 94863, Pseudomonas aeruginosa ATCC 14028 and Salmonella choleraesuis ATCC 14028) and fungus Candida albicans ATCC 18804. The fungi were cultivated in Malte Agar (for filamentous fungi) and yeast + Malt Agar (for non-filamentous fungi) medium for $72 \mathrm{~h}$, at $26^{\circ} \mathrm{C}$ and bacteria in Nutrient Agar medium for $24 \mathrm{~h}$, at $36^{\circ} \mathrm{C}$.

L. amazonensis (MHOM/BR88/BA-125 Leila strain) promastigotes were cultivated in Liver Infusion Tryptose (LIT) medium or Schneider (Sigma-Aldrich, St. Louis, MO, USA) medium supplemented with $10 \%$ fetal bovine serum (FBS; Gibco Invitogen Co., Tastrup, Denmark), $50 \mu \mathrm{g} \mathrm{mL}{ }^{-1}$ of gentamicin (Life, Carlsbad, CA, USA), $\mathrm{pH} 7.2$, at $26^{\circ} \mathrm{C}$. The parasites were counted daily using Neubauer chamber, during five days. Upon reaching the stationary phase of growth, new in vitro passages of the parasites were performed. The infectivity of the parasites was maintained through passages in BALB/c mice. All animal experiments and procedures were approved by the institution's committee on the ethical handling of laboratory animals (approved No. L-IGM-004/2019).

Bloodstream trypomastigotes forms of T. cruzi (Y strain) were obtained from supernatants of LLC-MK2 cells previously infected and maintained in RPMI-1640 medium (Sigma-Aldrich, St. Louis, MO, USA) supplemented with $10 \% \mathrm{FBS}$, and $50 \mu \mathrm{g} \mathrm{mL}^{-1}$ gentamicin at $37^{\circ} \mathrm{C}$ and $5 \% \mathrm{CO}_{2}$.

\section{Antibiotic and antifungal tests}

Broth microdilution method was used for determination of the minimum inhibitory concentration (MIC) according to the technical standards of the Clinical and Laboratory Standards Institute, with modifications. ${ }^{25,26}$ This broth microdilution assay was performed under aseptic conditions using a sterile 96 well plate. Stock solutions of the extracts in petroleum ether, fraction EPEL10, and methanol from the leaves, stems and stem bark were prepared in the dimethyl sulfoxide (DMSO) in the concentration of $2000 \mu \mathrm{g} \mathrm{mL}^{-1}$ (lupenone of $400 \mu \mathrm{g} \mathrm{mL}^{-1}$ ). The final concentrations of the extracts and fraction EPEL10 were tested in the range of 500 to $3.9 \mu \mathrm{g} \mathrm{mL}^{-1}$ and the lupenone in the 100 to $0.78 \mu \mathrm{g} \mathrm{mL}^{-1}$. The positive controls used were, respectively: benzylpenicillin $\left(1 \mathrm{mg} \mathrm{mL}^{-1}\right)$ for Gram-positive bacteria, geramycin $\left(200 \mu \mathrm{g} \mathrm{mL}^{-1}\right)$ for Gramnegative bacteria and ciclopirox olamine $\left(400 \mu \mathrm{g} \mathrm{mL}^{-1}\right)$ for fungus. The inoculum preparation was performed based on turbidity ( 0.5 on the McFarland scale, approximately $1.5 \times 10^{8}$ colony-forming unit $\left.(\mathrm{CFU}) \mathrm{mL}^{-1}\right)$. The fungi were incubated for $72 \mathrm{~h}$ at $26^{\circ} \mathrm{C}$ and bacteria in $24 \mathrm{~h}$ at $36^{\circ} \mathrm{C}$. The MIC was determined as the lowest concentration capable of visually inhibiting the growth of the microorganisms. The experiment was performed in triplicate. The assay to obtain the minimal microbicidal concentrations (MBC, for bacteria and MFC, for fungus) were conducted according to Souza-Neta and co-workers, ${ }^{26}$ without modifications.

\section{Viability assay against promastigotes forms of L. amazonensis}

Promastigotes of $L$. amazonensis $\left(1 \times 10^{6}\right.$ per well $)$ were cultivated in a 96-well plate containing Schneider's medium (Sigma-Aldrich, St. Louis, MO, USA) supplemented with 10\% FBS (Gibco Invitogen Co., Tastrup, Denmark) and $50 \mu \mathrm{g} \mathrm{mL}^{-1}$ gentamicin (Life, Carlsbad, CA, USA). Promastigotes were treated with six concentrations of lupenone diluted $1 / 3(20-0.625 \mu \mathrm{M})$ for $72 \mathrm{~h}$ at $26{ }^{\circ} \mathrm{C}$. Subsequently, $20 \mu \mathrm{L}$ per well of AlamarBlue (Invitrogen, Carlsbad, CA, USA) was added for $2 \mathrm{~h}$. The readings were performed using a spectrophotometer at 570 and 
$600 \mathrm{~nm}$ wavelengths. The percent inhibition of the axenic culture was determined based on the untreated control. The inhibitory concentration for $50 \%\left(\mathrm{IC}_{50}\right)$ was calculated based on the percent inhibition of parasite growth, related to negative controls, and accessed through concentration logarithm values followed by nonlinear regression curve fit.

\section{In vitro macrophage infection and treatment}

To evaluate the effect of the lupenone in the intracellular amastigote form, J774 macrophages (mouse macrophage-like cell line) were cultured in 24 -well plates $\left(2 \times 10^{5}\right.$ per well $)$ and infected with stationary-phase promastigotes of L. amazonensis at a ratio of 10:1, for $4 \mathrm{~h}$. Infected macrophages were treated with different concentrations of lupenone for $24 \mathrm{~h}$, in triplicate. Amphotericin B was used as a positive control. The cells were fixed in methanol and stained by Giemsa (Sigma-Aldrich, St. Louis, MO, USA). The percentage of infected macrophages and the number of amastigotes by macrophages were determined by counting 100 cells per slides, as previously described. ${ }^{27}$

\section{Ultrastructural analysis}

J774 macrophages infected with L. amazonensis were treated with lupenone for $24 \mathrm{~h}$ at $37{ }^{\circ} \mathrm{C}$ and $5 \% \mathrm{CO}_{2}$. After incubation, the parasites were fixed for $1 \mathrm{~h}$ at room temperature with $2 \%$ formaldehyde and $2.5 \%$ glutaraldehyde (Electron Microscopy Sciences, Hatfield, PA, USA) in sodium cacodylate buffer ( $0.1 \mathrm{M}, \mathrm{pH}$ 7.2). After fixation, the parasites were washed 4 times with $0.1 \mathrm{mM}$ sodium cacodylate buffer, $\mathrm{pH} 7.2$, and post-fixed with a $1 \%$ solution of osmium tetroxide (Sigma Chemical Company, St. Louis, MO, USA). Cells were subsequently dehydrated in increasing concentrations of acetone (30, 50, 70, 90 and 100\%) for 10 min at each step and embedded in Polybed resin (PolyScience family, Warrington, PA, USA). Ultrafine sections prepared using a Leica UC7 ultramicrotome, were collected, contrasted with uranyl acetate and lead citrate and observed under a JEOL TEM-1320 (JEOL, Tokyo, Japan) transmission electron microscope.

\section{Trypanocidal activity}

Trypomastigotes collected from the supernatants of LLC-MK2 cells were dispensed into 96-well plates at a cell density of $4 \times 10^{5}$ cells per well. Screening was performed with all the compounds in a single concentration of $25 \mu \mathrm{g} \mathrm{mL} \mathrm{m}^{-1}$. The plate was incubated for $24 \mathrm{~h}$ at $37^{\circ} \mathrm{C}$ and $5 \%$ of $\mathrm{CO}_{2}$. Aliquots of each well were collected and the number of viable parasites, based on parasite motility, was assessed in a Neubauer chamber. The percentage of inhibition was calculated in relation to untreated cultures. This experiment was repeated once, and benznidazole was used as the positive control.

\section{Cytotoxicity evaluation}

To determine the cytotoxicity of the extracts and lupenone, J774 cells were seeded into 96-well plates at a cell density of $1 \times 10^{4}$ cells per well in Dulbecco's modified Eagle medium (DMEM; Life Technologies, GIBCO-BRL, Gaithersburg, MD, USA) supplemented with 10\% FBS (Gibco Invitogen Co., Tastrup, Denmark), and $50 \mu \mathrm{g} \mathrm{mL}^{-1}$ of gentamycin (Novafarma, Anápolis, $\mathrm{GO}$, Brazil) and incubated for $24 \mathrm{~h}$ at $37^{\circ} \mathrm{C}$ and $5 \% \mathrm{CO}_{2}$. After that time, each test inhibitors were added at least in five concentrations, in triplicate, and incubated for $72 \mathrm{~h}$. Twenty $\mu \mathrm{L}$ per well of AlamarBlue (Invitrogen, Carlsbad, CA, USA) were added to the plates during $4 \mathrm{~h}$. Colorimetric readings were performed at 570 and $600 \mathrm{~nm}$ using a spectrophotometer. $\mathrm{CC}_{50}$ values (cytotoxicity concentration at $50 \%$ ) were calculated using data-points gathered from two independent experiments.

\section{Preparation and multi-element analysis}

The acid digestion of $A$. inundata samples-leaves, bark and stems (heartwood)-was performed using a commercial high-pressure laboratory microwave oven (Milestone Ethos 1600 Microwave Labstation, Sorisole, Italy) operating at a frequency of $2450 \mathrm{~Hz}$, with an energy output of $900 \mathrm{~W}$. This microwave digestion system was equipped with ten 100-mL tetrafluoromethoxy vessels and a ceramic vessel jacket. The maximum operating temperature and pressure were $180{ }^{\circ} \mathrm{C}, 1000 \mathrm{~W}$ and $35 \mathrm{bar}$, respectively, in $30 \mathrm{~min}$. The method used to determine the mineral composition of A. inundata samples was quick and simple, according to Santos Jr. et al.:28 approximately $0.25 \mathrm{~g}$ of each sample was inserted directly into a microwave-closed vessel and $7 \mathrm{~mL}$ of $65 \%\left(\mathrm{~m} \mathrm{~m}^{-1}\right) \mathrm{HNO}_{3}$ were added for $12 \mathrm{~h}$ in a predigestion at room temperature $\left(25^{\circ} \mathrm{C}\right)$. Then, $0.5 \mathrm{~mL}$ of $30 \%\left(\mathrm{~m} \mathrm{~m}^{-1}\right) \mathrm{H}_{2} \mathrm{O}_{2}$ were added to each vessel and subjected to digestion. After cooling, the samples were then diluted to $10 \mathrm{~mL}$. Metal contents of the final solution were determined by ICP OES.

An inductively coupled plasma optical emission spectrometer (ICP OES, VISTA PRO, Varian-Mulgrave, Australia) with axial viewing and a solid state detector was used for the simultaneous determination of the analytes of interest ( $\mathrm{Al}, \mathrm{As}, \mathrm{Ba}, \mathrm{Ca}, \mathrm{Cd}, \mathrm{Co}, \mathrm{Cr}, \mathrm{Cu}, \mathrm{Fe}, \mathrm{Hg}, \mathrm{K}, \mathrm{Mg}$, $\mathrm{Mn}, \mathrm{Mo}, \mathrm{Ni}, \mathrm{P}, \mathrm{Pb}, \mathrm{Se}, \mathrm{V}$ and $\mathrm{Zn}$ ). The optical system 
was calibrated using a multi-element stock solution for ICP OES, whereas a $5.0 \mathrm{mg} \mathrm{L}^{-1} \mathrm{Mn}$ standard solution was used for optical alignment. The spectral lines were selected according to the absence of spectral interference and appropriate sensitivity for determining elements at high and low concentrations, by studying the emission lines of the elements to be investigated. The lines that exhibited low interference, high analytical signal and background ratios were selected. The optimized parameters of ICP OES were: radio frequency power (RF) generator power $(1300 \mathrm{~W})$; plasma gas rate $\left(1.5 \mathrm{~mL} \mathrm{~min}^{-1}\right)$; auxiliary gas rate $\left(1.5 \mathrm{~mL} \mathrm{~min}^{-1}\right)$; nebulizer gas rate $\left(0.7 \mathrm{~mL} \mathrm{~min}^{-1}\right)$; sample uptake rate $\left(0.8 \mathrm{~mL} \mathrm{~min}^{-1}\right)$; injector tube diameter $(2.4 \mathrm{~mm})$ and signal integration time $(1 \mathrm{~s})$. The analytical wavelengths (nm) used for multi-elemental analysis were: Al (396.152); As (188.970); Ba (493.408); Ca (317.933); Cd (228.802); Co (228.616); Cr (284.325); Cu (324.754); Fe (259.939); Hg (253.652); K (404.721); Mg (280.217); Mn (257.610); Mo (202.032); Ni (221.648); P (213.617); $\mathrm{Pb}$ (217.000); Se (196.026); V (290.880); Zn (213.857).

\section{Validation studies}

The method was validated by performance parameters: stability, linearity, precision, accuracy, limit of detection, limit of quantification and matrix effect. ${ }^{29}$ Samples and multi-element solution stability were evaluated for $24 \mathrm{~h}$ at room temperature and kept at $37^{\circ} \mathrm{C}$ for $2 \mathrm{~h}$ in 0.01 and $0.1 \mathrm{~mol} \mathrm{~L}^{-1} \mathrm{HCl}$ by checking changes in the analytical signal after analyzed by ICP OES. Linearity was evaluated by linear regression of analytical curves ( 1.0 to $200.0 \mu \mathrm{g} \mathrm{mL}^{-1}$ for macro- and 1.0 to $50.0 \mu \mathrm{g} \mathrm{mL}^{-1}$ for microelements). Precision was evaluated through relative standard deviation (RSD) from the obtained data by analyzing solutions of macro- and microelements with a working concentration of 5 and $25 \mu \mathrm{g} \mathrm{mL}{ }^{-1}$, in six replicates.

The accuracy of the measurements was assessed using apple leaves certified reference material 1515 (CRM/NIST 1515) from the National Institute of Standards and Technology (Gaithersburg, MD, USA). In addition, a recovery study was conducted by adding known amounts $(5 \mu \mathrm{g})$ of each mineral in samples, for evaluation of accuracy. Limits of detection (LOD) and quantification (LOQ) were calculated using the concentration equivalent to three times the standard deviation $(3 \sigma)$ of the signal $(n=10)$ of the analytical blank solution, and the LOQ was calculated using $10 \sigma$ criterion $(n=10)$, respectively. The matrix effect was evaluated by comparing the slopes of curves obtained by external calibration with standard solutions in acid medium $\left(2 \mathrm{~mol} \mathrm{~L}^{-1} \mathrm{HNO}_{3}\right)$, from solutions of the digested samples by ICP OES.

\section{Statistical analysis}

The $\mathrm{IC}_{50}$ of leishmania growth and $\mathrm{CC}_{50}$ were calculated based in a nonlinear regression (curve fit) and the statistical analyses were made by one-way analysis of variance (ANOVA) and Newman-Keuls multiple comparison test using Prism 5.02 GraphPad Software. ${ }^{30}$ The critical level of significance was established for $p<0.05$. All experiments were done at least twice.

\section{Results and Discussion}

\section{Identification structural of the lupenone}

The structural identification of lupenone in the subfractions F3.24.4, F3.28.3 and F3.29.3 was performed analyzing their ${ }^{1} \mathrm{H}$ and ${ }^{13} \mathrm{C}$ NMR data (Supplementary Information (SI) section) and comparing it with those available in the literature. ${ }^{31-35}$ The ${ }^{1} \mathrm{H}$ NMR spectrum of the compound (Figure S1a, SI section) showed characteristic triterpenoid signals between $\delta_{\mathrm{H}} 0.67-1.92$, in addition to two broad singlets at $\delta_{\mathrm{H}} 4.58$ and 4.70 , typical for double bond reference to geminal olefinic hydrogens in C-29 and it can be concluded that it is a lupane skeleton. ${ }^{31}$ Further, the spectrum indicated the presence of seven methyl singlets at $\delta_{\mathrm{H}} 0.76,0.81,0.89,0.94,0.95,1.03$ and 1.69 (Figure S1b, SI section). These signals are in accordance with those of the literature for lupenone. ${ }^{32}$ The ${ }^{13} \mathrm{C}$ NMR spectrum displayed the signal at $\delta_{\mathrm{C}} 218.2$ (Figure S2a, SI section) characteristic of carbonyl, and the signals in $\delta_{\mathrm{C}} 109.4$ and 150.9 for olefinic carbons. ${ }^{33}$ It was also possible to identify chemical shifts of the following primary carbons: $\delta_{\mathrm{C}} 26.6 ; 21.0 ; 15.8 ; 16.0 ; 14.5 ; 18.0$ and 19.7, representing the carbons C23, C24, C25, C26, C27, C28 and C30, respectively (Figure S2b, SI section). After analyzing these spectral data and comparing them with the literature (Table 1) it was possible to identify that fractions F3.24.4, F3.28.3 and F3.29.3 are constituted by lupenone (Figure 1). ${ }^{34,35}$ Although lupenone has already been found in other species of Albizia (A. versicolor, A. schimperana and Albizia gummifera $)^{36}$ and $A$. lebbeck, ${ }^{37}$ its isolation in A. inundata is being reported for the first time, in this study.

The ${ }^{1} \mathrm{H}$ NMR spectra of the methanol extracts of the stem bark and leaves (Figures S3 and S4, SI section) showed signals for protons of the structural skeleton of derivatives triterpenes and steroids, among other metabolites, at $\delta_{\mathrm{H}}$ 3.06-3.51 (carbinolic protons); at $\delta_{\mathrm{H}} 4.98-5.56$ (olefinic protons); $\delta_{\mathrm{H}} 1.98-0.76$ and $\delta_{\mathrm{H}} 1.07-3.5$ (methyl and methylenic protons, respectively). Other signals at $\delta_{\mathrm{H}} 4.40-5.50$ suggest presence of the anomeric protons. In addition to these, aromatic protons at $\delta_{\mathrm{H}} 6.87-8.0$, mainly 


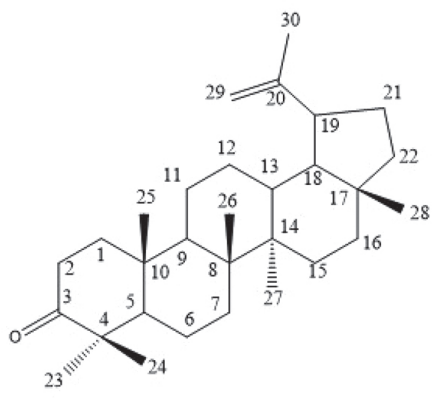

Figure 1. Chemical structure of lupenone.

Table 1. Lupenone ${ }^{13} \mathrm{CNMR}\left(125 \mathrm{MHz}, \mathrm{CDCl}_{3}\right.$ ) chemical shifts, compared to the values reported in the literature ( 50 and $75 \mathrm{MHz}, \mathrm{CDCl}_{3}$ )

\begin{tabular}{|c|c|c|c|}
\hline Carbon (C) & $\begin{array}{c}\delta_{\mathrm{C}} \text { (lupenone, } \\
125 \mathrm{MHz}, \\
\left.\mathrm{CDCl}_{3}\right) / \mathrm{ppm}\end{array}$ & $\begin{array}{c}\delta_{\mathrm{C}}(\text { Olea and } \\
\text { Roque, }{ }^{34} \\
50 \mathrm{MHz} \\
\left.\mathrm{CDCl}_{3}\right) / \mathrm{ppm}\end{array}$ & $\begin{array}{c}\delta_{\mathrm{C}}(\mathrm{Ahmad} \text { and } \\
\text { Atta-Ur-Rahman, } \\
75 \mathrm{MHz} \\
\left.\mathrm{CDCl}_{3}\right) / \mathrm{ppm}\end{array}$ \\
\hline 1 & 39.6 & 39.7 & 39.6 \\
\hline 2 & 34.1 & 34.0 & 34.1 \\
\hline 3 & 218.2 & 217.0 & 217.9 \\
\hline 4 & 47.9 & 47.3 & 47.3 \\
\hline 5 & 54.9 & 55.0 & 55.0 \\
\hline 6 & 19.7 & 19.8 & 19.6 \\
\hline 7 & 33.5 & 33.6 & 33.6 \\
\hline 8 & 40.8 & 40.9 & 40.9 \\
\hline 9 & 49.8 & 49.8 & 49.8 \\
\hline 10 & 36.9 & 37.0 & 36.9 \\
\hline 11 & 21.5 & 21.4 & 21.5 \\
\hline 12 & 25.1 & 25.1 & 25.2 \\
\hline 13 & 38.2 & 38.3 & 38.2 \\
\hline 14 & 43.0 & 43.0 & 42.9 \\
\hline 15 & 27.4 & 27.4 & 27.4 \\
\hline 16 & 35.5 & 35.6 & 35.6 \\
\hline 17 & 42.9 & 43.0 & 42.9 \\
\hline 18 & 48.2 & 48.2 & 48.3 \\
\hline 19 & 47.9 & 47.9 & 47.9 \\
\hline 20 & 150.9 & 150.5 & 150.7 \\
\hline 21 & 29.8 & 29.9 & 29.9 \\
\hline 22 & 40.0 & 40.0 & 40.0 \\
\hline 23 & 26.6 & 26.7 & 26.6 \\
\hline 24 & 21.0 & 21.1 & 21.0 \\
\hline 25 & 15.8 & 15.8 & 15.8 \\
\hline 26 & 16.0 & 16.0 & 15.9 \\
\hline 27 & 14.5 & 14.6 & 14.4 \\
\hline 28 & 18.0 & 18.1 & 18.0 \\
\hline 29 & 109.4 & 109.6 & 109.2 \\
\hline 30 & 19.7 & 19.4 & 19.3 \\
\hline
\end{tabular}

NMR: nuclear magnetic resonance; $\delta_{\mathrm{C}}$ : carbon displacement; ppm: parts per million. the ${ }^{1} \mathrm{H}$ NMR spectrum of the stem bark extract, which was most active, indicate the presence of the classes of the aromatic secondary metabolites (Figure S4, SI section).

A. inundata is still an unexplored species. In the literature, only Zhang et al. ${ }^{14}$ identified pentacyclic saponins isolated from the methanolic extract of $A$. inundata bark. Chemical investigations related to other Albizia species have led to the isolation of lignans, flavonoids, alkaloids, saponins, diterpenes, and others. Some species have been reported producing a wide range of triterpenoid saponins by Liu et al. ${ }^{4}$

Cao et al..$^{6}$ isolated three new oleanane triterpenoid saponins from the root of A. gummifera. Ikeda et al. ${ }^{8}$ isolated and elucidated the structures of three new saponins, julibrosidas from A. julibrissin. In the first report of saponin esters in dicotyledonous plants, Krief et al. ${ }^{7}$ isolated three new oleanane triterpenoid saponins, called A-C grandibracteosides, from the methanol extract from leaves of A. grandibracteata, a species widely consumed by primates in the Kibale/Uganda National Park.

\section{Cytotoxicity assessment}

In the Albizia genus, plants are known for their traditional medicinal uses for the treatment of mental disorders, insomnia, tumors, among other diseases. ${ }^{38,39}$ The plant extract and lupenone were evaluated against mammalian cells to determine the cytotoxicity. The petroleum ether extracts did not demonstrate cytotoxicity $\left(\mathrm{CC}_{50}\right.$ values $\left.>100 \mu \mathrm{g} \mathrm{mL}^{-1}\right)$. Lupenone exhibited $\mathrm{CC}_{50}=31.95 \mu \mathrm{g} \mathrm{mL}^{-1}$, being several times less cytotoxic in comparison with gentian violet $\left(\mathrm{CC}_{50}=1.16 \pm 0.7 \mu \mathrm{g} \mathrm{mL}^{-1}\right)$, the reference drug in this assay. In contrast, for the methanolic extracts of the bark, stem and leaves were obtained $\mathrm{CC}_{50}$ values of $10.26( \pm 0.6)$, $12.52( \pm 0.7)$ and $1.567( \pm 0.9) \mu \mathrm{g} \mathrm{mL}{ }^{-1}$, respectively. These results show potential cytotoxic of these compounds. In a previous report ${ }^{14}$ was demonstrated that two triterpenic saponins isolated from $A$. inundata presented activity against tumor cells, with $\mathrm{IC}_{50}$ of 1.0-3.8 $\mu \mathrm{g} \mathrm{mL} \mathrm{m}^{-1}$. These data suggest a possible antitumor activity of the methanolic extracts and lupenone isolated from A. inundata.

In this study, antitumor activity of extracts and lupenone was not evaluated. In literature, Zhang et al..$^{14}$ carried out studies on the pharmacological potential of A. inundata against tumor melanoma cells (B16F10 and SKMEL28), from two triterpenic saponins isolated from the methanolic extract from the aerial parts, obtaining the $\mathrm{IC}_{50}$ value of $1.0-3.8 \mu \mathrm{g} \mathrm{mL}{ }^{-1}$, with satisfactory results regarding the other substances analyzed in the research against the same tumor cell lines. In addition, Wei et al. ${ }^{15}$ evaluated the cytotoxic activity of oleanane triterpenoid saponins against human colon cells (HCT116). Therefore, there are perspectives 
for evaluation of extracts and lupenone isolated from A. inundata, in other cancer cell lines.

In literature, few studies have demonstrated the tumor activity of the genus Albizia. Cao et al. ${ }^{6}$ studied the ethanolic extract of the root of A. gummifera and of three triterpenoid saponins of the oleanane type isolated, two compounds presented cytotoxicity against the human ovarian cancer cell line (A2780). Krief et al. ${ }^{7}$ evaluated the crude extract and the pure compounds of A. grandibracteata, which demonstrated significant in vitro inhibitory activity against tumor cell lines (KB and MCF7). Ikeda et al. ${ }^{8}$ reported crude fraction cytotoxicity of A. julibrissin. Lenta et al. ${ }^{9}$ evaluated the methanolic extract of Albizia zygia (DC) J. F. Macbr. bark and showed significant results related to cytotoxic activity in cells of the L-6 line (mouse skeletal muscle myoblasts) with $\mathrm{IC}_{50}$ value of $4.5 \mu \mathrm{g} \mathrm{mL} \mathrm{m}^{-1}$. Melek et al. ${ }^{10}$ performed a phytochemical and biological study of the A. procera species and highlighted cytotoxicity against HEPG2 cells with $\mathrm{IC}_{50}$ values of 9.3 and $10 \mu \mathrm{g} \mathrm{mL}{ }^{-1}$. Lacroix et al. ${ }^{11}$ reported cytotoxicity against human tumor cells from squamous cell carcinoma of the mouth (KB), obtaining $\mathrm{IC}_{50}$ value of $21 \mu \mathrm{g} \mathrm{mL} \mathrm{L}^{-1}$, from extracts from the leaves of A. grandibracteata.

\section{Antibacterial and antifungal activities}

The results for antibacterial and antifungal activities of A. inundata (petroleum ether extract from leaves; extracts in methanol from the leaves, stems and stem bark and of lupenone, isolated of the petroleum ether extract from leaves) was evaluated against three Gram positive, three Gram negative strains and Candida albicans. Minimum bactericidal concentration (CBM) and minimum fungicidal concentration (CFM) are presented in Table 2.
Among the samples tested, the methanolic extract of the stem bark (SMSB) was the most active against all the microorganisms tested, with MICs values in the range of 3.9-125 $\mu \mathrm{g} \mathrm{mL}^{-1}$. Although this extract had low bacteriostatic selectivity, its bactericidal effect on Gram-negative bacteria $S$. choleraesuis and $P$. aeruginosa was elevated with values of MMCs of 62.5 and $125 \mu \mathrm{g} \mathrm{mL} \mathrm{m}^{-1}$, respectively. These antibacterial effect of the extracts can probably be inferred by the presence of triterpenic saponins, among other metabolites, according to a preliminary phytochemical study of aerial parts of a specimen of A. inundata. ${ }^{15}$ The antimicrobial assay demonstrated that the methanol extract from the leaves (EML) showed activity against S. choleraesuis, B. subtilis, M. luteus and C. albicans with MICs of 250, 125, 15.63 and $250 \mu \mathrm{g} \mathrm{mL}^{-1}$, respectively.

The petroleum ether extract from the leaves showed no antibacterial effect, however, lupenone, which was isolated from this extract, showed selective bacteriostatic effect for M. luteus with MIC of $50 \mu \mathrm{g} \mathrm{mL}$. The synergism of the compound mixture masked the antimicrobial effect of this extract. Lupenone has been known to have anti-inflammatory, anti-diabetic, antitumor and, antiviral activity, ${ }^{40}$ but the bacteriostatic effect on M. luteus has not been reported.

\section{Antileishmanial activity}

Non-cytotoxic concentrations of compounds were tested for antiparasitic activity. The leishmanicidal effect of lupenone and extracts was evaluated against promastigote and amastigote forms of $L$. amazonensis. This triterpene significantly reduced promastigotes proliferation, with an $\mathrm{IC}_{50}$ value of $20 \mu \mathrm{M}$, being less potent than amphotericin $\mathrm{B}$, a reference drug for leishmaniasis treatment, which presented an $\mathrm{IC}_{50}$ of $0.09 \mu \mathrm{M}$. However,

Table 2. Screening for the antifungal and antibacterial activities of the extracts and lupenone of A. inundata

\begin{tabular}{|c|c|c|c|c|c|c|c|}
\hline \multirow{3}{*}{ Sample } & \multicolumn{7}{|c|}{ Microorganisms MICs (MMCs) / $\left(\mu \mathrm{g} \mathrm{mL}^{-1}\right)$} \\
\hline & \multicolumn{3}{|c|}{ Gram-positive bacteria } & \multicolumn{3}{|c|}{ Gram-negative bacteria } & \multirow{2}{*}{$\begin{array}{c}\text { Fungi } \\
\text { C. albicans }\end{array}$} \\
\hline & S. aureus & M. luteus & B. subtilis & S. choleraesuis & P. aeruginosa & E. coli & \\
\hline EML & $>500$ & $15.63(125)$ & $125(500)$ & $250(500)$ & $>500$ & $>500$ & $250(>500)$ \\
\hline SMSB & $15.63(31.25)$ & $3.91(3.91)$ & $31.25(31.25)$ & $31.25(62.5)$ & $125(125)$ & $125(>125)$ & $62.5(>500)$ \\
\hline SEM & $125.0(250)$ & $7.81(31.25)$ & $125(250)$ & $125(>125)$ & $500(>500)$ & $>500$ & $125(>500)$ \\
\hline EPEL & $>500$ & $>500$ & $>500$ & $>500$ & $>500$ & $>500$ & $>500$ \\
\hline Lupenone & $>100$ & $50(>50)$ & $>100$ & $>100$ & $>100$ & $>100$ & $>100$ \\
\hline Benzylpenicilin & 0.008 & 0.031 & 0.008 & & & & \\
\hline Geramycin & & & & 0.39 & 0.39 & 0.39 & \\
\hline Loprox (ciclopirox olamine) & & & & & & & 6.25 \\
\hline
\end{tabular}

MIC: minimum inhibitory concentration; MMC: minimum microbicidal concentration; concentrations tested of the extracts and fractions (500 to $\left.3.91 \mu \mathrm{g} \mathrm{mL} L^{-1}\right)$, lupenone (100 to $\left.0.78 \mu \mathrm{g} \mathrm{mL}^{-1}\right)$, antibiotics: benzylpenicillin $(1 \mu \mathrm{g} \mathrm{mL}-1)$ for Gram-positive bacteria; geramycin $\left(50-0.39 \mu \mathrm{g} \mathrm{mL}{ }^{-1}\right)$ for Gram-negative bacteria and ciclopirox olamine $\left(100-0.78 \mu \mathrm{g} \mathrm{mL}^{-1}\right)$ for fungus. EML: crude methanolic extracts of leaves; SMSB: crude methanolic extracts of stem bark; SEM: crude methanolic extracts of stem; EPEL: petroleum ether of the leaves. 
lupenone was several times less cytotoxic in comparison with amphotericin B (Table 3). The extracts did not show antileishmanial activity. In literature, there are no reports on antileishmanial activities of $A$. inundata and there are few data on the effects of terpenes against different species of leishmania. ${ }^{41-43}$ Monoterpenes isolated from essential oils and aromatic plants presented $\mathrm{IC}_{50}$ for promastigotes higher than those found in the present work (48- $65 \mu \mathrm{M}) .{ }^{44}$ $\alpha$-Amyrin, 11-oxo- $\alpha$-amyrone and 11-oxo- $\alpha$-amyrin, triterpenes obtained from Cola nitida, presented an $\mathrm{IC}_{50}$ values against promastigotes of L. amazonensis of 19.42 and $11.6 \mu \mathrm{g} \mathrm{mL}^{-1}$, respectively. The lipophilicity of triterpenes might facilitate penetration through lipid bilayer of cellular membranes, increasing the toxicity against leishmania species. ${ }^{45}$

To evaluate the effects of lupenone against amastigotes, J774 macrophages were infected with L. amazonensis promastigotes and treated at different concentrations $(5$, 10 and $20 \mu \mathrm{M}$ ) of the compound for $24 \mathrm{~h}$. Although there was no significant reduction in the percentage of infected macrophages at all concentrations tested, treatment with lupenone significantly reduced the number of amastigotes per macrophage at a concentration of $20 \mu \mathrm{M}$ (Figure 2). Lupenone presented an $\mathrm{IC}_{50}$ value of $20.6 \mu \mathrm{M}$ against amastigotes. The lupenone was more effective than lupeol, isolated from aerial parts of Vernonia scorpioides, which showed an $\mathrm{IC}_{50}$ of $40.73 \mu \mathrm{g} \mathrm{mL}^{-1}$ against amastigotes of L. amazonensis. ${ }^{46}$ In another study, $\alpha$-bisabolol terpene showed an $\mathrm{IC}_{50}$ of $10.70 \mu \mathrm{g} \mathrm{mL}^{-1}$ against amastigotes of L. amazonensis, with higher $\mathrm{IC}_{50}$ values than lupenone. ${ }^{47}$ Lupenone and extracts were tested in initial screening against Trypanosoma cruzi trypomastigotes, and no activity was observed (data not shown).

To evaluate the effects of lupenone on the parasite structures, J774 macrophages were infected with L. amazonensis and treated with lupenone at $20 \mu \mathrm{M}$. After $24 \mathrm{~h}$ of treatment, ultrastructural changes were evaluated by the transmission electron microscopy. Untreated parasites showed normal morphology, without alterations (Figures 3a and $3 b$ ). The presence of lipid inclusions was observed in the cytoplasm of amastigotes treated with lupenone, suggesting an accumulation of abnormal lipids and precursors in the parasite (Figures $3 \mathrm{c}$ and $3 \mathrm{~d}$ ). ${ }^{47}$ Interestingly, similar alterations were found in promastigotes of L. amazonensis treated with an essential oil from Vanillosmopsis arborea and (-) $\alpha$-bisabolol, an alcohol sesquiterpene. ${ }^{48,49}$ The appearance of lipids inclusions indicates that lupenone might affect the lipid biosynthesis pathways, a promise target in the leishmania drug discovery field. ${ }^{50,51}$

Table 3. Cytotoxic concentration for $50 \%$ of cells $\left(\mathrm{CC}_{50}\right)$, inhibitory concentration for $50 \%$ of parasites $\left(\mathrm{IC}_{50}\right)$ and selectivity index

\begin{tabular}{lcccc}
\hline Compound & $\mathrm{CC}_{50} \mathrm{M} \varphi \mathrm{J} 774 / \mu \mathrm{M}$ & $\begin{array}{c}\mathrm{IC}_{50} \text { promastigotes of } \\
\text { L. amazonensis } / \mu \mathrm{M}\end{array}$ & $\begin{array}{c}\text { Selectivity index } \\
\text { (promastigotes) }\end{array}$ & $\begin{array}{c}\mathrm{IC}_{50} \text { amastigotes of } \\
\text { L. amazonensis / } \mu \mathrm{M}\end{array}$ \\
\hline Lupenone & $37.5 \pm 9.0$ & $20.0 \pm 0.5$ & 1.8 & $\begin{array}{c}\text { Selectivity index } \\
(\text { amastigotes) }\end{array}$ \\
Amphotericin B & $3.3 \pm 0.5$ & $0.09 \pm 0.02$ & 36.6 & $0.6 \pm 2.4$ \\
Gentian violet & $0.8 \pm 0.1$ & - & - & $0.05 \pm 0.01$ \\
\hline
\end{tabular}

$\mathrm{CC}_{50}$ : cytotoxic concentration for $50 \%$ of cells; M $\varphi$ J774: J774 macrophages; $\mathrm{IC}_{50}$ : inhibitory concentration for $50 \%$ of parasites.

(a)

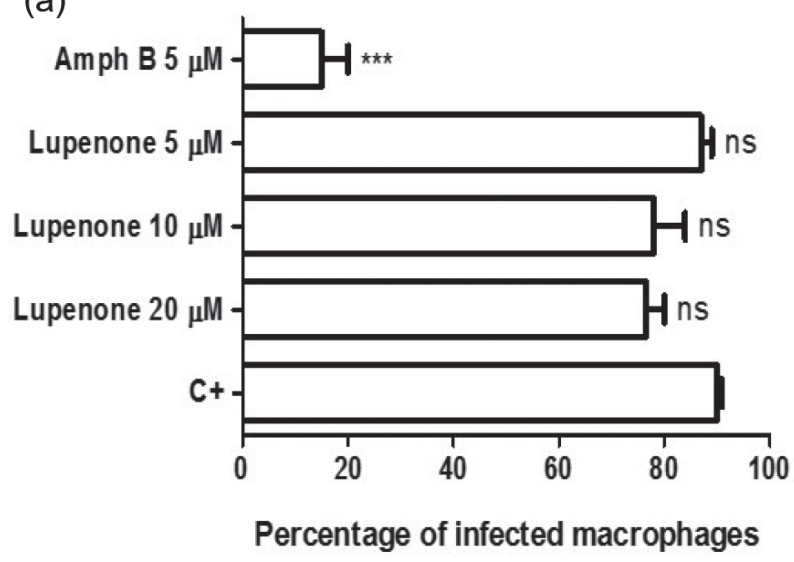

(b)

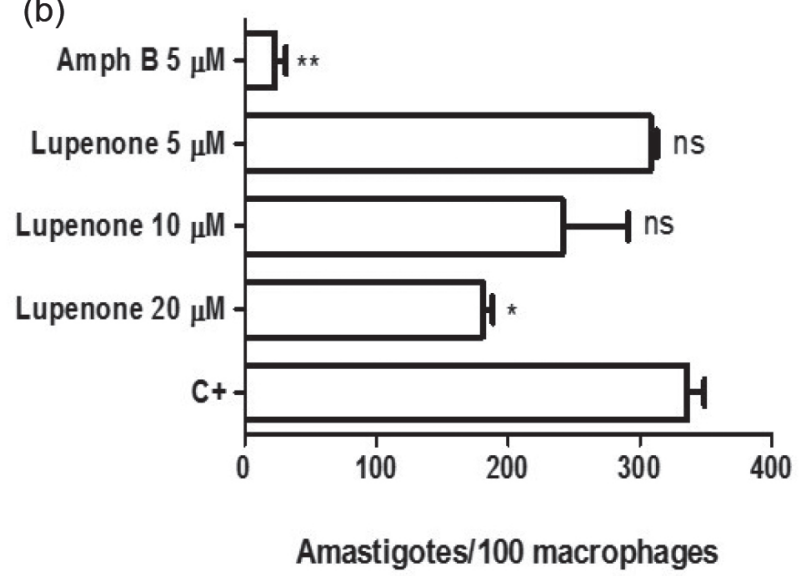

Figure 2. Effect of lupenone against L. amazonensis infected macrophages. J774 macrophages were infected with L. amazonensis (at a ratio of 10:1) and treated with lupenone $(5,10$ and $20 \mu \mathrm{M})$ after $4 \mathrm{~h}$ of infection. The percentage of infected macrophages (a) and number of intracellular amastigotes (b) were determined after $24 \mathrm{~h}$ of treatment. Amphotericin B (Amph B; $5 \mu \mathrm{M}$ ) was used as a reference drug. $* P<0.05$ compared to $\mathrm{C}+$ group; $* * P<0.01$ compared to $\mathrm{C}+$ group; $* * * P<0.001$ compared to $\mathrm{C}+$ group, ns: not significant. 


\section{Multi-element analysis}

The method was validated for stability and, samples and multi-element solutions were stable within $24 \mathrm{~h}$. Linearity was evaluated and a good linearity was obtained for all observed lines, with determination coefficients $\left(\mathrm{R}^{2}\right)$ in the range from 0.9994 to 0.9998 . Precision was assessed and the relative standard deviation (RSD) values were lower than $10 \%$, indicating the high precision of this method.

A recovery test of the analytical procedure was carried out for the elements under study in leaves of $A$. inundata by spiking ( $5 \mu \mathrm{g}$ of each analyte) the analyzed samples with aliquots of metal standards and then reanalyzing the samples. This sample was chosen for this test due to its available mass. The obtained recovery values, in the range of $90-107 \%$, showed that there are no signs of systematic errors due to operation effects of the added analyte, such as losses during the process. The results showed good
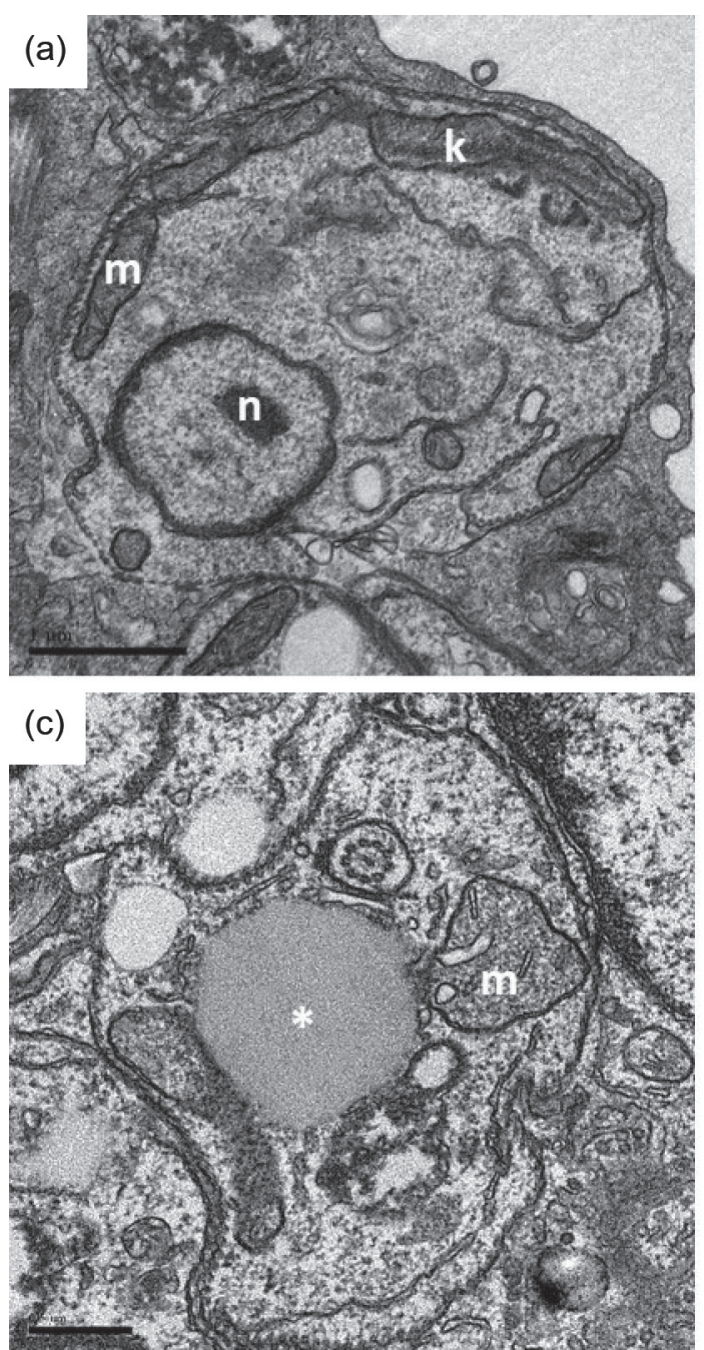

agreement with the reference values of the CRM/NIST 1515-apple leaves (Table 4). The obtained recovery values, in the range of 90 to $110 \%$, showed good accuracy of the method. It was possible to verify similarities in the amount of macro and microelements when comparing the values obtained in the CRM 1515 with the leaves sample of A. inundata, mainly for the elements $\mathrm{Al}, \mathrm{K}, \mathrm{Mg}$ and V. It is suggested that this similarity can be attributed to the same part of the plant, of both materials. When analyzing the bark and the stem it was possible to establish similarities for the micronutrients $\mathrm{Cr}, \mathrm{K}, \mathrm{P}$ and $\mathrm{Zn}$, present in the studied plant.

The LODs and LOQs obtained for $\mathrm{Al}, \mathrm{As}, \mathrm{Ba}, \mathrm{Ca}, \mathrm{Cd}$, $\mathrm{Co}, \mathrm{Cr}, \mathrm{Cu}, \mathrm{Fe}, \mathrm{Hg}, \mathrm{K}, \mathrm{Mg}, \mathrm{Mn}, \mathrm{Mo}, \mathrm{Ni}, \mathrm{P}, \mathrm{Pb}, \mathrm{Se}, \mathrm{V}$ and $\mathrm{Zn}$ determined by ICP OES are shown in Table 4. The residual acidity of the digests was $<3.0 \mathrm{~mol} \mathrm{~L}-1$. The slopes of the calibration curves for each element do not show significant variations, at $95 \%$ confidence. These results showed that
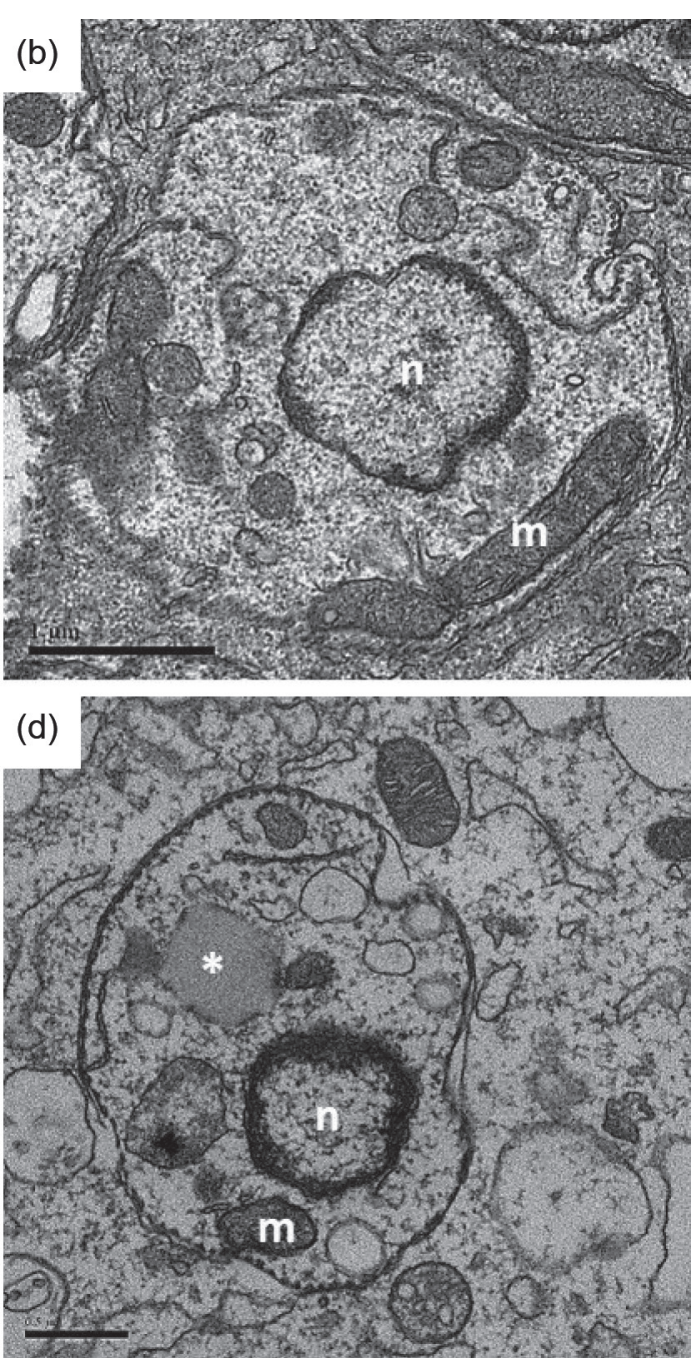

Figure 3. Transmission electron microscopy of intracellular amastigotes of L. amazonensis after treatment with lupenone (20 $\mu \mathrm{M})$. Untreated intracellular parasites presenting organized cytoplasm and organelles with normal morphology $(\mathrm{a}, \mathrm{b})$. Parasites treated with lupenone at concentration of $20 \mu \mathrm{M}$ exhibiting unchanged cytoplasm and organelles, but with lipid inclusions (c, d). n: nucleus; m: mitochondria; k: kinetoplast; *: lipid inclusion. 
the matrix effect is not significant for the measures in ICP OES under the selected operating conditions.

The content ( $\mu \mathrm{g} \mathrm{g}^{-1}$ or $\mathrm{mg} \mathrm{g}^{-1}$ ) of 19 elements (Al, As, $\mathrm{Ba}, \mathrm{Ca}, \mathrm{Cd}, \mathrm{Co}, \mathrm{Cr}, \mathrm{Cu}, \mathrm{Fe}, \mathrm{Hg}, \mathrm{K}, \mathrm{Mg}, \mathrm{Mn}, \mathrm{Mo}, \mathrm{Ni}, \mathrm{P}, \mathrm{Pb}$, $\mathrm{V}$ and $\mathrm{Zn}$ ) in the areas (leaf, bark and stem/heartwood) of the Albizia inundata plant was determined. As, $\mathrm{Ba}, \mathrm{Cd}, \mathrm{Co}$, $\mathrm{Hg}, \mathrm{Mo}$ e $\mathrm{Pb}$, in all the investigated samples, were found to be below the LOD value of ICP OES.

No data were found in the literature for Albizia species, regarding elemental composition. The results indicated that the aerial parts of $A$. inundata contain amounts of $\mathrm{Al}, \mathrm{Ca}, \mathrm{Cr}, \mathrm{Cu}, \mathrm{Fe}, \mathrm{K}, \mathrm{Mg}, \mathrm{Mn}, \mathrm{Ni}, \mathrm{P}, \mathrm{V}$ and Zn (Table 4). Concentrations of $\mathrm{Al}, \mathrm{Cr}, \mathrm{Cu}, \mathrm{Fe}$ and $\mathrm{Mn}$ varied widely in the samples studied. The results obtained for the macro $(\mathrm{K}$ and $\mathrm{P}$ ) and micronutrients ( $\mathrm{Al}, \mathrm{Cr}, \mathrm{Cu}, \mathrm{Fe}$ and $\mathrm{Zn}$ ), present in the aerial parts of $A$. inundata, showed that leaves presented the highest values of these elements, when compared to the other parts of the plant. These variations of concentration may have occurred due to variations in the distribution of these elements in the biological cycle in the plant, their incorporation into the aerial structures of A. inundata, changes in soil and other geoclimatic conditions, among other variables. ${ }^{52}$ Especially for $\mathrm{Cr}$, it is suggested that some type of soil or sample contamination may have occurred during collection, transport, packaging and/or preparation. Elci et $a l .{ }^{53}$ proposed a selective extraction of chromium(VI) using a leaching procedure with sodium carbonate from some plant leaves, soil and sediment samples by graphite furnace atomic absorption spectrometry (GF AAS), after acid digestion with mixture of $\mathrm{HClO}_{4}+\mathrm{HNO}_{3}+\mathrm{H}_{2} \mathrm{O}_{2}$ of plants (tomato and fig leaves). The authors quantified a high $\mathrm{Cr}^{\mathrm{VI}}$ and total chromium content in growing tomato and fig leaves, in soil of land close to the leather tanning industry region. Altundag et al., ${ }^{54}$ in Sakarya, Turkey, studied the influence of selected soil and plant properties and their potential impacts on human health in urban environments by two artificial digestion models (stomach and intestinal). Soil and plants samples were dissolved by an acid mixture of $\mathrm{HNO}_{3}(65 \%) / \mathrm{HCl}(37 \%)$. The authors concluded that trace element levels transmitted from soil and plants (parsley and lettuce) to humans were low, in range of 0 and $68 \%$ for $\mathrm{Al}$ and $\mathrm{Cd}$, respectively.

Establishing the multi-element composition of plants with therapeutic potential is necessary to contribute to the health organs because the plants may be used as sources of nutrients to animal and human health. In literature, studies have determined multi-element in plants and others biological samples by spectroscopic techniques. Marques and Nóbrega ${ }^{55}$ developed a fast and simple flow-batch extraction procedure for screening of macro and micronutrients in dried plant leaves by ICP OES. Barin et al. ${ }^{56}$ determined $\mathrm{Al}, \mathrm{Ba}, \mathrm{Ca}, \mathrm{Cr}, \mathrm{Cu}, \mathrm{Mg}, \mathrm{Mn}$, $\mathrm{Ni}, \mathrm{Sr}, \mathrm{V}$ and $\mathrm{Zn}$ by ICP OES in foliar tissues: oregano (Origanum majorana sp.), salsa (Petroselinum crispum), basil (Ocimum basilicum), coriander (Coriandrum sativum) and chives (Allium schoenoprasum). Pytlakowska et al. ${ }^{57}$ determined 13 trace elements by ICP OES (Al, B, Ba, Fe, Zn, $\mathrm{Mn}, \mathrm{Mg}, \mathrm{K}, \mathrm{Na}, \mathrm{P}, \mathrm{Cu}$, Sr and $\mathrm{Ca}$ ) in herbs and their infusions:

Table 4. Concentrations of $\mathrm{Ca}, \mathrm{K}, \mathrm{Mg}, \mathrm{P}, \mathrm{Al}, \mathrm{Cr}, \mathrm{Cu}, \mathrm{Fe}, \mathrm{Mn}, \mathrm{Ni}, \mathrm{V}$ and $\mathrm{Zn}$ in leaves, bark and stem (heartwood) from A. inundata and CRM/NIST 1515-apple leaves, after digestion in microwave oven. Values obtained for LOD and LOQ, by digestion in a microwave oven (mean \pm standard deviation, $\mathrm{n}=3,95 \%$ confidence level)

\begin{tabular}{|c|c|c|c|c|c|c|c|c|c|c|c|c|}
\hline \multirow{3}{*}{$\begin{array}{l}\text { Sample/ } \\
\text { elements }\end{array}$} & \multicolumn{12}{|c|}{ Concentration } \\
\hline & $\mathrm{Al}$ & $\mathrm{Ca}$ & $\mathrm{Cr}$ & $\mathrm{Cu}$ & $\mathrm{Fe}$ & $\mathrm{K}$ & $\mathrm{Mg}$ & $\mathrm{Mn}$ & $\mathrm{Ni}$ & $\mathrm{P}$ & $\mathrm{V}$ & $\mathrm{Zn}$ \\
\hline & $\begin{array}{c}396.153 \mathrm{~nm} / \\
\left(\mu \mathrm{g} \mathrm{g}^{-1}\right)\end{array}$ & $\begin{array}{c}317.933 \mathrm{~nm} / \\
\left(\mathrm{mg} \mathrm{g}^{-1}\right)\end{array}$ & $\begin{array}{c}284.325 \mathrm{~nm} / \\
\left(\mu \mathrm{g} \mathrm{g}^{-1}\right)\end{array}$ & $\begin{array}{c}324.752 \mathrm{~nm} / \\
\left(\mu \mathrm{g} \mathrm{g}^{-1}\right)\end{array}$ & $\begin{array}{c}259.939 \mathrm{~nm} / \\
\left(\mu \mathrm{g} \mathrm{g}^{-1}\right)\end{array}$ & $\begin{array}{c}404.21 \mathrm{~nm} / \\
\left(\mathrm{mg} \mathrm{g}^{-1}\right)\end{array}$ & $\begin{array}{c}280.271 \mathrm{~nm} / \\
\left(\mathrm{mg} \mathrm{g}^{-1}\right)\end{array}$ & $\begin{array}{c}257.610 \mathrm{~nm} / \\
\left(\mu \mathrm{g} \mathrm{g}^{-1}\right)\end{array}$ & $\begin{array}{c}221.648 \mathrm{~nm} / \\
\left(\mu \mathrm{g} \mathrm{g}^{-1}\right)\end{array}$ & $\begin{array}{c}213.617 \mathrm{~nm} / \\
\left(\mathrm{mg} \mathrm{g}^{-1}\right)\end{array}$ & $\begin{array}{c}290.880 \mathrm{~nm} / \\
\left(\mu \mathrm{g} \mathrm{g}^{-1}\right)\end{array}$ & $\begin{array}{c}213.857 \mathrm{~nm} / \\
\left(\mu \mathrm{g} \mathrm{g}^{-1}\right)\end{array}$ \\
\hline $\begin{array}{l}\text { CRM/NIST } 1515 \\
\text { (certified value) / } \\
\left(\mu \mathrm{g} \mathrm{g}^{-1}\right)\end{array}$ & $286.0 \pm 9.0$ & $1.5 \pm 0.1$ & - & $5.6 \pm 0.2$ & - & $1.6 \pm 0.1$ & $0.27 \pm 0.01$ & $54.0 \pm 3.0$ & $0.91 \pm 0.12$ & - & $0.26 \pm 0.03$ & $12.3 \pm 0.1$ \\
\hline $\begin{array}{l}\text { CRM/NIST } 1515 \\
\text { (determined } \\
\text { value) } /\left(\mu \mathrm{g} \mathrm{g}^{-1}\right)\end{array}$ & $\begin{array}{c}271.0 \pm 0.1 \\
(94.7)^{\mathrm{a}}\end{array}$ & $\begin{array}{c}1.5 \pm 0.2 \\
(99.3)^{\mathrm{a}}\end{array}$ & $5.8 \pm 0.8$ & $\begin{array}{l}5.2 \pm 1.3 \\
(92.7)^{\mathrm{a}}\end{array}$ & $8.4 \pm 2.1$ & $\begin{array}{c}1.5 \pm 0.3 \\
(90.1)^{\mathrm{a}}\end{array}$ & $\begin{array}{c}0.25 \pm 0.01 \\
(92.6)^{\mathrm{a}}\end{array}$ & $\begin{array}{c}59.2 \pm 9.9 \\
(109.6)^{\mathrm{a}}\end{array}$ & $\begin{array}{c}0.82 \pm 0.03 \\
\quad(90.1)^{\mathrm{a}}\end{array}$ & $0.24 \pm 0.05$ & $\begin{array}{c}0.27 \pm 0.02 \\
(103.8)^{\mathrm{a}}\end{array}$ & $\begin{array}{l}12.1 \pm 1.0 \\
(98.7)^{\mathrm{a}}\end{array}$ \\
\hline $\begin{array}{l}\text { A. inundata } \\
\text { (leaves) }\end{array}$ & $212.7 \pm 0.9$ & $1.0 \pm 0.1$ & $20.3 \pm 1.3$ & $11.6 \pm 0.8$ & $32.1 \pm 6.2$ & $1.5 \pm 0.3$ & $0.24 \pm 0.03$ & $243.1 \pm 15.4$ & $0.29 \pm 0.01$ & $0.23 \pm 0.04$ & $0.28 \pm 0.05$ & $26.9 \pm 2.9$ \\
\hline $\begin{array}{l}\text { A. inundata } \\
\text { (bark) }\end{array}$ & $96.2 \pm 0.4$ & $1.0 \pm 0.1$ & $11.9 \pm 0.8$ & $9.1 \pm 1.4$ & $9.2 \pm 1.1$ & $1.2 \pm 0.5$ & $0.69 \pm 0.02$ & $265.4 \pm 34.3$ & $0.38 \pm 0.02$ & $0.11 \pm 0.02$ & $0.16 \pm 0.04$ & $13.1 \pm 1.2$ \\
\hline $\begin{array}{l}\text { A. inundata } \\
\text { (stems- } \\
\text { heartwood) }\end{array}$ & $10.7 \pm 0.1$ & $2.9 \pm 0.3$ & $11.8 \pm 0.3$ & $6.0 \pm 1.7$ & $33.0 \pm 0.4$ & $1.2 \pm 0.1$ & $0.31 \pm 0.01$ & $21.0 \pm 7.1$ & $0.16 \pm 0.01$ & $0.17 \pm 0.02$ & $0.06 \pm 0.01$ & $14.3 \pm 0.9$ \\
\hline $\mathrm{LOD} /\left(\mu \mathrm{g} \mathrm{g}^{-1}\right)$ & 0.002 & 0.009 & 0.017 & 0.0001 & 0.003 & 0.034 & 0.011 & 0.001 & 0.002 & 0.101 & 0.004 & 0.009 \\
\hline $\mathrm{LOQ} /\left(\mu \mathrm{g} \mathrm{g}^{-1}\right)$ & 0.007 & 0.029 & 0.058 & 0.0008 & 0.011 & 0.115 & 0.040 & 0.005 & 0.008 & 0.336 & 0.017 & 0.030 \\
\hline
\end{tabular}

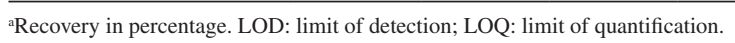


chamomile (Matricaria chamomilla L.), peppermint (Mentha xpiperita), melissa (Melissa officinalis), sage (Salvia officinalis), nettle (Urtica dioica), linden tree (Tilia vulgaris) and St. John's wort (Hypericum calycinum) consumed for medicinal purposes in Poland. Santos Jr. et al. ${ }^{28}$ determined the elemental composition of nine medicinal plants and phytomedicines: Maytenus ilicifolia Mart. ex Reiss ("espinheira santa"), Piper methysticum G. Foster (kawa-kawa), Pfaffia glomerata (Spreng.) Pedersen (Brazilian ginseng), Uncaria tomentosa (cat's claw), Rhamnus purshiana (sacred bark), Hypericum perforatum $\mathrm{L}$. (St. John's wort), Ptychopetalum olacoides Bentham ("marapuama"/potency wood), Anemopaegma arvense Vell. ("catuaba") and Euterpe oleracea Mart. (açai) by ICP OES, after microwave digestion.

\section{Conclusions}

This study made possible the identification, for the first time, of a pentacyclic triterpene (lupenone) isolated from the petroleum ether extract from leaves and its fractions from Albizia inundata (Mart.) Barneby \& J.W.Grimes species, being an inedited contribution to the specie, showing a chemotaxonomic importance for Albizia genus.

In addition, natural products from $A$. inundata revealed antimicrobial activity against bacteria, fungi and Leishmania amazonensis. Methanol extract (leaves) showed activity against $S$. choleraesuis, B. subtilis, M. luteus and C. albicans. Lupenone demonstrated antibacterial activity against $M$. luteus. Interestingly, leishmanial activity might be related to interference in the lipid biosynthesis pathways. No activity was observed when lupenone was tested against Trypanosoma cruzi trypomastigotes. Therefore, based on the results obtained, potential biological activity of A. inundata was observed.

The determination of the element composition of A. inundata samples-leaves, bark and stems (heartwood) using ICP OES with axial viewing required a simple pretreatment procedure of the sample, featuring simple and reproducible method results. Lastly, using ICP OES, we found large concentrations of $\mathrm{Cu}, \mathrm{Fe}, \mathrm{Mn}$ and $\mathrm{Zn}$ which makes these samples as additional sources of these macronutrients. These results may be useful for obtaining further information and for the formation of a mineral composition database on Albizia species.

\section{Supplementary Information}

Supplementary data associated with this article can be found, free of charge, at http://jbcs.sbq.org.br as a PDF file.

\section{Acknowledgments}

The authors are grateful to the following Brazilian agencies: Bahia State Research Support Foundation (FAPESB), Brazilian National Council for Scientific and Technological Development (CNPq) and "Coordenação de Aperfeiçoamento de Pessoal de Nível Superior-Brasil (CAPES)" for research fellowships and, Oswaldo Cruz Foundation (Fiocruz) and State University of Bahia (UNEB) for financial support in laboratories and infrastructure.

\section{Author Contributions}

E. M. J. A. performed the experimental work of phytochemical analysis, multi-element composition and antimicrobial activity, wrote and reviewed the manuscript. J. S. T., D. K. C. S., T. B. S., C. S. M., M. B. P. S. and E. T. G. performed the cytotoxicity assays and antiparasitic activity, analyzed the results and wrote part of this manuscript. M. G. A. K., H. N. B. and C. G. F. analyzed the general results and wrote part of this manuscript, L. C. S. N. and A. F. S. J. headed the investigation and conceived the experimental plan.

\section{References}

1. Imededdine, N.; Ind. Crops Prod. 2011, 33, 30.

2. Dutra, A. S.; Medeiros Filho, S.; Oliveira, D. F.; Rev. Caatinga 2008, 21, 75 .

3. Viana, E. O. R.; Cruz, M. F. S. J.; Silva, M. J.; Pereira, G. M.; Silva, B. P.; Tinoco, L. W.; Parente, J. P.; Carbohydr. Res. 2019, $471,105$.

4. Liu, R.; Ma, S. G.; Liu, Y. X.; Yu, S. S.; Chen, X. G.; Zhang, J. J.; Carbohydr. Res. 2010, 345, 1877.

5. Sobeh, M.; Rezq, S.; Sabry, O. M.; Abdelfattah, M. A. O.; El Raey, M. A.; El-Kashak, W. A.; El-Shazly, A. M.; Mahmoud, M. F.; Wink, M.; Biomed. Pharmacother. 2019, 115, 108882.

6. Cao, S.; Norris, A.; Miller, J. S.; Ratovoson, F.; Razafitsalama, J.; Andriantsiferana, A.; Rasamison, V. E.; Tendyke, K.; Suh, T.; Kingston, D. G. I.; J. Nat. Prod. 2007, 70, 361.

7. Krief, S.; Thoison, O.; Sevenet, T.; Wrangham, R. W.; Lavaud, C.; J. Nat. Prod. 2005, 68, 897.

8. Ikeda, T.; Fujiwara, S.; Araki, K.; Kinjo, J.; Nohara, T.; Miyoshi, T.; J. Nat. Prod. 1997, 60, 102.

9. Lenta, B. N.; Vonthron-Sénécheau, C.; Soh, R. F.; Tantangmo, F.; Ngouela, S.; Kaiser, M.; Tsamo, E.; Anton, R.; Weniger, B.; J. Ethnopharmacol. 2007, 111, 8.

10. Melek, F. R.; Miyase, T.; Ghaly, N. S.; Nabil, M.; Phytochemistry 2007, 68, 1261.

11. Lacroix, D.; Prado, S.; Kamoga, D.; Kasenene, J.; Namukobe, J.; Krief, S.; Dumontet, V.; Mouray, E.; Bodo, B.; Brunois, F.; J. Ethnopharmacol. 2011, 133, 850. 
12. Baldin, T.; Marchiori, J. N. C.; Balduinia 2014, 46, 25.

13. Marchiori, J. N. C.; Alves, F. S.; Balduinia 2012, 33, 21.

14. Zhang, H.; Samadi, A. K.; Rao, K. V.; Cohen, M. S.; Timmermann, B. N.; J. Nat. Prod. 2011, 74, 477.

15. Wei, G.; Cui, S.; Luan, W.; Wang, S.; Hou, Z.; Liu, Y.; Liu, Y.; Cheng, M.; Eur. J. Med. Chem. 2016, 113, 92.

16. Rogero, S. O.; Lugão, A. B.; Ikeda, T. I.; Cruz, A. S.; Mat. Res. 2003, 6, 317.

17. Fayad, J. A.; Fontes, P. C. R.; Cardoso, A. A.; Finger, F. L.; Ferreira, F. A.; Hortic. Bras. 2002, 20, 90.

18. Souza, S. O.; Costa, S. S. L.; Santos, D. M.; Pinto, J. S.; Garcia, C. A. B.; Alves, J. P. H.; Araujo, R. G. O.; Spectrochim. Acta, Part B 2014, 96, 1.

19. Qing-Hua, Y.; Li, Y.; Qing, W.; Xiao-Qin, M.; J. Saudi Chem. Soc. 2012, 16, 287.

20. Razic, S.; Onjia, A.; Dogo, S.; Slavkovic, L.; Popovic, A.; Talanta 2005, 67, 233.

21. Kalny, P.; Fijałek, Z.; Daszczuk, A.; Ostapczuk, P.; Sci. Total Environ. 2007, 381, 99.

22. Sá, R. R.; Caldas, J. C.; Santana, D. A.; Lopes, M. V.; Santos, W. N. L.; Korn, M. G. A.; Santos Jr., A. F.; Food Chem. 2019. 273,15 .

23. Gentschev, G. D.; Stafilov, T.; Ivanov, E. H.; Eurasian J. Anal. Chem. 2010, 5, 104.

24. Marin, S.; Lacrimioara, S.; Cecilia, R.; J. Plant Dev. 2011, 18 , 87.

25. Clinical Laboratory Standards Institute (CLSI); Performance Standards for Antimicrobial Susceptibility Testing, available at https://clsi.org/media/2663/m100ed29_sample.pdf, accessed in March 2020.

26. Araújo, F. M.; Dantas, M. C. S. M.; Silva, L. S.; Aona, L. Y. S.; Tavares, I. F.; Souza-Neta, L. C.; Ind. Crops Prod. 2017, 105, 203.

27. Guimarães, E. T.; Lima, M. S.; Santos, L. A.; Ribeiro, I. M.; Tomassini, T. B.; Ribeiro dos Santos, R.; Teixeira, M. M.; dos Santos, W. L. C.; Soares, M. B. P.; J. Antimicrob. Chemother. 2009, 64, 84.

28. Santos Jr., A. F.; Matos, R. A.; Andrade, E. M. J.; Santos, W. N. L.; Magalhães, H. I. F.; Costa, F. N.; Korn, M. G. A.; J. Braz. Chem. Soc. 2017, 28, 376.

29. International Conference on Harmonisation (ICH); Validation of Analytical Procedures: Text and Methodology Q2 (R1), available at https://www.fda.gov/regulatory-information/ search-fda-guidance-documents/q2-r1-validation-analyticalprocedures-text-and-methodology, accessed in March 2020

30. GraphPad Prism, version 5.02; GraphPad Software Inc., San Diego, USA, 2008.

31. Costa, D. A.; Chaves, M. H.; Silva, W. C. S.; Costa, C. L. S.; Acta Amazonica 2010, 40, 207.

32. Prakash, C. V. S.; Prakash, I.; Res. J. Pharm. Sci. 2012, 1, 23.
33. Mutai, C.; Abatis, D.; Vagias, C.; Moreau, D.; Roussakis, C.; Roussis, V.; Phytochemistry 2004, 65, 1159.

34. Olea, R. S. G.; Roque, N. F.; Quim. Nova 1990, 13, 278.

35. Ahmad, V. U.; Atta-Ur-Rahman; Pentacyclic Triterpenoids (Handbook of Natural Products Data); Elsevier Science: Amsterdam, 1994, p. 1029.

36. Rukunga, G. M.; Waterman, P. G.; Fitoterapia 2001, 72, 188.

37. Gupta, R. S.; Kachhawa, J. B. S.; Chaudhary, R.; Phytomedicine 2006, 13, 277.

38. Cheng, Z. Q.; Yang, D. A. N.; Liu, Y. Q.; Hu, J. M.; Jiang, H. Z.; Wang, P. C.; Li, N.; Zhou, J.; Zhao, Y. X.; J. Braz. Chem. Soc. 2010, 21, 1766.

39. Meirelles, M. N.; Araújo Jorge, T. C.; Souza, W.; Z. Parasitenkd. 1982, 68,6 .

40. Xu, F.; Huang, X.; Wu, H.; Wang, X.; Biomed. Pharmacother. 2018, 103, 198.

41. Yaluff, G.; Vega, C.; Alvarenga, N.; Acta Trop. 2017, 168, 41.

42. Oliveira, C.; Moura, M.; Lopes, A.; de Andrade, P.; da Silva, H.; Figueiredo, C.; Parasitol. Res. 2009, 104, 1053.

43. de Medeiros, M.; da Silva, A.; Citó, A.; Borges, A.; de Lima, S.; Lopes, A.; Figueiredo, R.; Parasitol. Int. 2011, 60, 237.

44. Youssefi, R. M; Moghaddas, E.; Tabari, M. A.; Moghadamnia, A. A.; Hosseini, M. S.; Farash, H. R. B.; Ebrahimi, A. M.; Mousavi, N. N.; Fata, A.; Maggi, F.; Petrelli, R.; Dall'Acqua, S.; Benelli, G.; Sut, S.; Molecules 2019, 24, e2072.

45. Frankenberger, L.; Mora, T.; de Siqueira, C. D.; FilippinMonteiro, F. B.; de Moraes, M. H.; Biavatti, M. W.; Sandjo, L. P.; Phytochem. Anal. 2018, 29, 577.

46. Machado, V. R.; Sandjo, L. P.; Pinheiro, G. L.; Moraes, M. H.; Steindel, M.; Pizzolatti, M. G.; Biavatti, M. W.; Nat. Prod. Res. 2018, 32, 275.

47. Vannier-Santos, M. A.; de Castro, S. L.; Curr. Drug Targets 2009, 10, 246.

48. Colares, A. V.; Almeida-Souza, F.; Taniwaki, N. N.; Souza, C. D. S. F.; da Costa, J. G. M.; Calabrese, K. D. S.; Abreu-Silva, A. L.; J. Evidence-Based Complementary Altern. Med. 2013, 2013, 727042 .

49. Rottini, M. M.; Amaral, A. C.; Ferreira, J. L.; Silva, J. R.; Taniwaki, N. N.; Souza, C. S. F.; d'Escoffier, L. N.; AlmeidaSouza, F.; Hardoim, D. J.; Gonçalves-da-Costa, S. C.; Calabrese, K. S.; Exp. Parasitol. 2015, 148, 66.

50. Emami, S.; Tavangar, P.; Keighobadi, M.; Eur. J. Med. Chem. 2017, 135, 241.

51. Yamamoto, E. S.; Jesus, J. A.; Bezerra-Souza, A.; Laurenti, M. D.; Ribeiro, S. P.; Passero, L. F. D.; Curr. Top. Med. Chem. 2018, 18, 2338.

52. Maiga, A.; Diallo, D.; Bye, R.; Paulsen, B. S.; J. Agric. Food Chem. 2005, 53, 2316.

53. Elci, L.; Divrikli, U.; Akdogan, A.; Hol, A.; Cetin, A.; Soylak, M.; J. Hazard. Mater. 2010, 173, 778. 
54. Altundag, H.; Albayrak, S.; Dundar, M. S.; Tuzen, M.; Soylak, M.; Biol. Trace Elem. Res. 2015, 168, 276.

55. Marques, T. L.; Nóbrega, J. A.; Microchem. J. 2017, 134, 27.

56. Barin, J. S.; Pereira, J. S. F.; Mello, P. A.; Knorr, C. L.; Moraes, D. P.; Mesko, M. F.; Nóbrega, J. A.; Korn, M. G. A.; Flores, E. M. M.; Talanta 2012, 94, 308.
57. Pytlakowska, K.; Kita, A.; Janoska, P.; Połowniak, M.; Kozik, V.; Food Chem. 2012, 135, 494.

Submitted: December 22, 2019

Published online: April 14, 2020 